\title{
The Effect Of Hand Wash Training On Hand Higyene Behavior In Elementary School Students at SDAI Baznas South Sulawesi
}

\author{
Akbar Asfar*, Sudarman, Haeril Amir \\ Program Studi Ilmu Keperawatan FKM UMI Makassar \\ *akbar.asfar@umi.ac.id
}

\begin{abstract}
Hand washing activities at this time have not become a cultural community in Indonesia. Handwashing habits must be accustomed early on, especially in elementary school children because one source of disease transmission is unclean hands and contaminated with microorganisms in the form of bacteria and viruses. This study aims to determine the effect of 6-step hand washing training on Hand Higyene behavior in elementary school students at SDAI BAZNAS South Sulawesi in 2020.

The research method is a quasi experiment with the design used is the pretest-posttest control group design. The population taken in this study are school children in SDAI BAZNAS South Sulawesi. The population of the study were 75 students with a sampling technique that is Total Sampling. Data collection techniques with questionnaires and direct observation before and after training 6 steps hand washing. The data collected was analyzed by the Wilcoxon test

The results showed there was an influence of 6 steps hand washing training with Hand Higyene Behavior (Knowledge, Attitudes and Actions) on Elementary School students at SDAI BAZNAS South Sulawesi with $\mathrm{p}=0,000<0.005$.

Thus it was concluded that health education about hand washing had a major influence on behavior change and it was suggested that the need to continue to increase the knowledge and awareness of the community especially students in terms of washing hands, especially in the era of the Covid 19 pandemic.
\end{abstract}

Keywords: Hand Higyene, Elementary School Students, 6 steps Wash your hands 


\section{STRADA Jurnal Ilmiah Kesehatan}

DOI: $10.30994 /$ sjik.v9i2.333

ISSN: 2252-3847 (print); 2614-350X (online)

Vol.9 No.2 November 2020 Page.528-534

\section{BACKGROUND}

Where children begin to get learning or skills. Children will easily accept and get learning because the knowledge or skills possessed by children are still less than adults. Healthy behavior for children is important towards healthy living in the future, a healthy lifestyle continues to be fostered and developed so that children have the potential as agents of change to behave cleanly and healthy can be an example for friends, relatives, family and community (Hikmah, 2015).

The most dangerous carrier of germs is the hand. Therefore, it is very important to know and remember that hand washing is a very effective behavior to prevent the spread and transmission of diseases such as diarrhea. Hand washing is very important especially in children to avoid infections that can be dangerous. then it should encourage children to always wash their hands before doing activities or after doing activities (Setiawan, Asmarani, \& Sari, 2017). Hand washing is one of the sanitary measures by cleaning the hands and fingers using water and soap. By humans to be clean and break the chain of germs (Lipinwati, 2018).

The United Nations organization dealing with child welfare issues, the United Nations Children's Fund (UNICEF) found washing hands with soap can also reduce 50\% the incidence of influenza (Putri, 2012). Based on data from WHO diarrhea and ISPA (acute respiratory inspection) which is an infectious disease is still a health problem in Indonesia. data obtained from the United States CDC (Center Disease Control), there were 10,080 deaths with more than $80 \%$ of deaths due to diarrhea (WHO, 2018).

The total number of students in SDAI BAZNAS South Sulawesi Makassar is 75 students. interviews with SDAI BAZNAS South Sulawesi teachers found that many students did not wash their hands after playing and many students washed their hands modestly without using soap.

\section{METHODS}

This research is an analytical survey research using the pre experimental approach method with one group pre and post test design. This research will be conducted at SDAI BAZNAS, South Sulawesi Province and total populations 75 student with total sampling technique.

\section{RESULTS}

Univariate data results obtained after conducting statistical tests illustrating the response characteristics studied are explained in table 1

\section{Characteristics Of Respondents By Age and Sex}

Data related to the description of respondents based on age and gender are listed in table 1 below. 
Table 1. Characteristics Of Respondents By Age and Sex

\begin{tabular}{lcc}
\hline Characteristics & Total $(\mathbf{n})$ & Presentations (\%) \\
\hline Age & & \\
6 Years & 8 & 10,7 \\
7 Years & 16 & 21,3 \\
8 Years & 14 & 18,7 \\
9 Years & 8 & 10,7 \\
10 Years & 5 & 6,7 \\
11 Years & 12 & 16,0 \\
112 Years & 12 & 16,0 \\
Gender & & 53,3 \\
Male & 40 & 46,7 \\
Female & 35 &
\end{tabular}

Seen from table 1 above, it can be seen that the most age is $>7$ years $(21,3 \%)$, male gender with the number of 40 respondents $(53,3 \%)$.

Hand Hygiene Knowledge

Table 2. The Effect of 6-Step Handwashing Training on Hand Hygiene Knowledge in Primary School Children at SDAI BAZNAS Sul-Sel Makassar

\begin{tabular}{ccccc}
\hline Knowledge & \multicolumn{2}{c}{ (Pre Test) } & \multicolumn{2}{c}{ (Post Test) } \\
& $\mathrm{n}$ & $\%$ & $\mathrm{~N}$ & $\%$ \\
\hline Enough & 38 & 50,7 & 72 & 96,0 \\
Less & 37 & 49,3 & 3 & 4,0 \\
Total & 75 & 100.0 & 75 & 100.0 \\
\hline
\end{tabular}

From table 2 above it is distribution of respondents note that from 75 respondents based on knowledge, prior to the training it was seen that the knowledge of hand washing 6 steps is sufficient knowledge of $50.7 \%$ and less $49.3 \%$. Whereas after the training, there was an increase in knowledge, marked by the reduction in the category of less than $49.3 \%$ to $4.0 \%$, while the sufficient category from $50.7 \%$ increased to $69.0 \%$.

\section{Hand Hygiene Attitude}

Table 3. The Effect of 6-Step Handwashing Training on Hand Hygiene Attitude in Primary School Children at SDAI BAZNAS Sul-Sel Makassar

(Pre Test) (Post Test)

\begin{tabular}{ccccc} 
Attitude & $\mathrm{n}$ & $\%$ & $\mathrm{~N}$ & $\%$ \\
\hline Positive & 20 & 26,7 & 60 & 80,0 \\
Negative & 55 & 73,3 & 15 & 20,0 \\
Total & 75 & 100.0 & 75 & 100.0 \\
\hline
\end{tabular}




\section{STRADA Jurnal Ilmiah Kesehatan}

DOI: $10.30994 /$ sjik.v9i2.333

ISSN: 2252-3847 (print); 2614-350X (online)

Vol.9 No.2 November 2020 Page.528-534

Table 3 about the distribution of respondents is known that of 75 respondents based on attitude before being given training that has a positive attitude as much (26.7\%) and negative as much as $73.3 \%$. Whereas after the training, a significant attitude change was seen, namely that those who had a negative attitude decreased from $73.3 \%$ to $20.0 \%$ while those who had a positive attitude increased from $26.7 \%$ to $80.0 \%$.

Action Hand Hygiene

Table 4. The Effect of 6-Step Handwashing Training on Action Hand Hygiene in Primary School Children at SDAI BAZNAS Sul-Sel Makassar

\begin{tabular}{ccccc}
\hline Action & \multicolumn{2}{c}{ (Pre Test) } & \multicolumn{2}{c}{ (Post Test) } \\
& $\mathrm{n}$ & $\%$ & $\mathrm{~N}$ & $\%$ \\
\hline Good & 14 & 18,7 & 59 & 78,7 \\
Less & 61 & 81,3 & 16 & 21,3 \\
Total & 75 & 100.0 & 75 & 100.0 \\
\hline
\end{tabular}

Table 4 about the distribution of respondents is known that from 75 respondents based on action before being given training that is good action as much as $18.7 \%$ and less as much as $81.3 \%$. Whereas after the training, there was an increase in good hand washing from $18.7 \%$ to $78.7 \%$ and the actions lacked from $81.3 \%$ to $21.3 \%$.

The 6-step handwashing training has a significant influence on hand hygiene behavior which includes knowledge, attitudes and actions with a statistical value of $p<0,000$.

\section{DISCUSSION}

\section{Effects of 6-step hand washing training on knowledge of hand hygiene in elementary school children}

Statistical test results using the Wilcoxon test, obtained knowledge with pre-test and post-test categories of $p=0,000$. This means that there is an influence of 6-step hand washing training knowledge on Hand hygiene behavior in elementary school children at SDAI Baznas Sul-Cell.

The results of this study are in line with the results of a study conducted by Nasyrah Wati, Nani Yuniar (2016) with the title Effect of Video Intervention Interventions on Knowledge, Attitudes and Actions About Handwashing with Soap on Students of Kabawo Elementary School that out of the 51 children studied there was knowledge of children about washing the hand has increased ie the number in the pre-test has increased from 33 children to 43 children with a significant value of $p=0.002$ so that this hypothesis is accepted that there is an influence between knowledge before and after the intervention. The results of this study are in line with the results of research conducted by Sri Rahayu in (2017) on the Effect of Comic Media Giving on Knowledge and Attitudes Regarding CPTS for Class V Students at SDN 026 Loa Janan from 40 children studied, there was an increase in the results of 16 children with less knowledge to $0 \%$ with $p=0.00$. Strengthened by the theory of (Nurdin, 2018) that knowledge is the result of knowing, and this happens after someone senses a certain object. Sensing, smell, taste, and touch. Most are obtained through the eyes and ears. One's knowledge can be obtained through education, mass media exposure (access to information), economy (income) social relations (socio-cultural environment), and experience. Knowledge includes behaviors that emphasize remembering such as remembering ideas and phenomena or events. 


\section{STRADA Jurnal Ilmiah Kesehatan}

DOI: $10.30994 /$ sjik.v9i2.333

ISSN: 2252-3847 (print); 2614-350X (online)

Vol.9 No.2 November 2020 Page.528-534

\section{Effects of 6-step hand washing training on hand hygiene attitudes in elementary school children}

The statistical test results using the Wilcoxon test, obtained the attitudes of children with the category of pre-test and post-test that is $p=0,000$. It means that there is an influence between attitude and 6-step hand washing training on Hand hygiene behavior in elementary school children at SDAI Baznas Sul-Sel. The results of this study are in line with the results of research conducted by (Wati, Yuniar, \& Paridah, 2017) with the title Effect of Video Intervention Interventions on Knowledge, Attitudes and Actions About Handwashing with Soap on Students of Kabawo Elementary School that of the 51 children studied there were attitudes of children about washing hands has increased namely a high number in pre-test has increased from 27 children to 40 children with a significant value of $\mathrm{p}=0.001$ so that this hypothesis is accepted that there is an influence between attitude before and after the intervention. Researcher's assumption, this study shows the influence of 6-step hand washing training on the attitude of hand hygiene in elementary school children this is because when children get information, children gain understanding so that their knowledge increases. Having given enough information to develop that knowledge along with the process of ongoing interaction will make the knowledge acquired to be something that is integrated with the individual and will affect the child's attitude. This is because when children know the importance of washing hands for them, the mind responds indirectly to conduct an attitude in accordance with what they know.

\section{Effects of 6-step hand washing training on hand hygiene measures in elementary school children}

Statistical test results using the Wilcoxon test, obtained by the child's actions with the category pre-test and post-test $p=0.000$. This means that there is an influence between actions with 6-step hand washing training on Hand hygiene behavior in elementary school children at SDAI Baznas Sul-Sel. .The results of this study are in line with the results of research conducted by (Wati, Yuniar, \& Paridah, 2017) with the title Effect of Video Intervention Interventions on Knowledge, Attitudes and Actions About Handwashing with Soap on Students of Kabawo Elementary School, that of the 51 children studied there were children's actions about washing hands has increased namely a high number in pre-test has increased from 13 children to 41 children with a significant value of $p=0,000$ so that this hypothesis is accepted that there is an influence between the actions before and after the intervention. The results of this study are also in line with Ni Kadek Rastini and Ni Made Rahmawati in (2018) with the title Differences in Use of Lecture Method of Combination Media Vidio on Knowledge and Handwashing with Soap Students from 56 children there is an increase in action that is $4.36 \%$ to $11.45 \%$ so that the value obtained $p=0.000$ means that there is a significant effect of actions before and after the lecture and video views. After the same research, the researchers assumed that the results showed that there was an effect of 6-step hand washing training on hand hygiene measures in elementary school children. because when researchers provide training, researchers also provide door prize sessions so that children are really enthusiastic about doing hand washing 6 steps. In addition there are adequate facilities such as running water and soap. Can be proven by the post-test of increased children's awareness. 


\section{STRADA Jurnal Ilmiah Kesehatan}

DOI: $10.30994 /$ sjik.v9i2.333

ISSN: 2252-3847 (print); 2614-350X (online)

Vol.9 No.2 November 2020 Page.528-534

\section{CONCLUSION}

There is an effect of 6-step hand washing training on the hand hygiene behavior of elementary school students of SDAI BAZNAS South Sulawesi

\section{REFERENCES}

Aini, D. F. (2018). Self Esteem Pada Anak Usia Sekolah Dasar Untuk Pencegahan Kasus Bullying. Retrieved Februari 4, 2019, from Jurnal Pemikiran dan Pengembangan SD: http://ejournal.umm.ac.id

Depkes. (2013). Lima Momen Saat Praktek Membersihkan Tangan. Jakarta: Deprtemen kesehatan Republik indonesia.

Firdaus, \& Agustina. (2018). Analisis Usia Perilaku Cuci Tangan Dengan Kejadian Diare di SDN Rangkah 1 Surabaya. Retrieved November 29, 2018, from Prosiding Seminar Nasional GERMAS 2018: http://journal2.unusa.ac.id/index.php/SNG/article/view/422

Hidayat, A. A. (2012). Pengantar Ilmu Keperawatan Anak 1 (1st ed.). Jakarta: Salemba Medika.

Hikmah, N. (2015). Perilaku Mencuci Tangan Pada SD Negeri 3 Gagak Sipat Boyolali. Retrieved Mei 01, 2019, from Jurnal Materniti: http://ejurnal.akbidcm.ac.id/index.php/maternity/article/view/36/34

Kahusadi, O. A., Tamurang, M. N., \& Punuh, M. I. (2018). Pengaruh Penyuluhan Kebersihan Tangan Hand Hyegine Terhadap perilaku Siswa SD GMIM 76 Maliambao Kecamatan Likupang Barat Kabupaten Minahasa Utara. Retrieved Mei 01, 2019, from Kesmas:https://ejournal.unsrat.ac.id/index.php/kesmas/article/view/21869

Kemenkes. (2014). Perilaku Mencuci Tangan Pakai Sabun Di Indonesia. Jakarta: Pusat Data Informasi Kementrian Kesehatan RI.

Kholid, A. (2014). Promosi Kesehatan. Jakarta: Raja Grafindo.

Listiowati, Nilamsari, E., \& Lisa. (2015). Efektifitas Pemberian Simulasi Hand Hygiene Terhadap Kepatuhan Hand Hygiene Petugas Non Medis di Rumah Sakit PKU Muhammadiyah Yogyakarta. Retrieved Februari 9, 2019, from Research Repository: http://repository.umy.ac.id/handle/123456789/2132

Listiowati, Nilamsari, E., \& Lisa. (2015). Efektifitas Pemberian Simulasi Hand Hygiene Terhadap Kepatuhan Hand Hygiene Petugas Non Medis di Rumah Sakit PKU Muhammadiyah Yogyakarta. Retrieved Februari 9, 2019, from Research Repository: http://repository.umy.ac.id/handle/123456789/2132

Notoatmodjo, S. (2012). Metodologi Penelitian Kesehatan. Jakarta: Rineka Cipta.

Nurdin, I. (2018). Hubungan Memotong Kuku Dan Cuci Tangan Pakai Sabun (CPTS) Di Sekolah Dengan Kejadian Diare Pada Siswa Kelas XI Di SMPN 36 Kelurahan Lapak Dalam Samarinda Seberang. Retrieved Mei 01, 2019, from UMKT: https://dspace.umkt.ac.id/handle/463.2017/938

Riskesda. (2013). Penyakit-penyakit Yang Dapat Menyerang Anak. Jakarta: Riset Badan Litbangkes.

Setiawan, D. I., Asmarani, F. L., \& Sari, D. R. (2017). Pengaruh Penyuluhan Kesehatan Menggunakan Media Video dan Bernyanyi Terhadap Keterampilan Cuci Tangan Pakai Sabun (CTPS) Pada Siswa TK PKK Indriarini Yogyakarta . Retrieved Februari 3, 2019, from Jurnal Keperawatan Respati Yogyakarta: http://nursingjurnal.respati.ac.id 


\section{STRADA Jurnal Ilmiah Kesehatan}

DOI: $10.30994 /$ sjik.v9i2.333

ISSN: 2252-3847 (print); 2614-350X (online)

Vol.9 No.2 November 2020 Page.528-534

Sugianto, V. (2018). Faktor Yang Berhubungan Dengan Hand Hygiene Pada Perawat di Ruang Inap Rumah Sakit Ibnu Sina YW-UMI. Makassar: FKM Universitas Muslim Indonesia.

Wati, N., Yuniar, N., \& Paridah. (2017, Januari). Pengaruh Intervensi Penayangan Vidio Terhadap Pengetahuan Sikap Dan Tindakan Tentang Cuci Tangan Pakai Sabun Pada Siswa SDN Kabawo . Retrieved Mei 01, 2019, from jimkesmas: https://scholar.google.co.id/scholar?hl=id\&as_sdt=0\%2C5\&q=pengaruh+interven si+penayangan+vidio+terhadap+pengetahuan $\% 2 \mathrm{C}+$ sikap+dan+tindakan+tentang+ cuci+tangan+pakai+sabun+pada+siswa+sdn+10+kabawo+tahun+2016\&btng $=$

WHO. (2018). Identifikasi Bakteri Staphylococcus Sp Pada Handphone dan Analisis Praktek Personal Hygiene. Retrieved Februari 1, 2019, from World Health Organization: http://who.int 